\title{
PEDIATRIC FACIAL NERVE NEUROPATHY: IMPROVEMENT OF THE OUTCOMES BASED ON CORRECTION OF AUTONOMIC DYSFUNCTION AND REDOX PROCESSES
}

\section{Iryna Liskevych ${ }^{1}$ \\ Mykola Pityk ${ }^{2}$}

DOI: https://doi.org/10.30525/978-9934-588-15-0-67

Abstract. The problem of expansion of the effective treatment of facial nerve neuropathy in children remains valid, since this pathology is most common among acute lesions of cranial nerves and has the first place among the diseases of the peripheral nervous system. The perspective in this direction is to study markers of autonomic dysfunction and hypoxia, such as lactate and pyruvate in the blood, as they reflect changes of decreased tissue oxygenation. On the basis of examinations among 122 children with acute facial nerve neuropathy aged 6 to 17 years, a significant increase in lactate and pyruvate reduction in the blood was found, most pronounced in severe dysfunction of the "facial nerve - facial muscles» (V degree on a House-Brackmann scale). Significant decreasing in lactate and pyruvate expanse, especially in patients who received thiotriazolin, could be an evidence of its role and effectiveness on the redox processes, one of the mechanisms for the implementation of which is to activate lactate-dehydrogenase reaction. It results in transformation lactate into pyruvate, leading to a decrease in edema and acidosis, which are important links in the pathogenesis of facial nerve neuropathy. Generally pediatric facial nerve neuropathy most often has positive prognosis with complete recovering, thought complications occurred in 3,3\% of cases. The proposed scheme of treatment provides improvement of outcomes, particularly reduce the duration of treatment and incidence of complications such as contracture of mimic muscles.

\footnotetext{
${ }^{1} \mathrm{PhD}$, Associate Professor at Department of Neurology and Neurosurgery, Ivano-Frankivsk National Medical University, Ukraine

${ }^{2}$ Doctor of Medical Sciences,

Professor at Department of Neurology and Neurosurgery

Ivano-Frankivsk National Medical University, Ukraine

(C) Iryna Liskevych, Mykola Pityk
} 


\section{Introduction}

Facial nerve neuropathy is the most common disease of the cranial nerve in children, which occurs acutely, and is the first among diseases of the peripheral nervous system. Its prevalence is 5-7 cases per 100 thousand, with the same frequency among boys and girls [6, p. 59; 18, p. 161; 19, p. 85].

Most researchers consider neuropathies of the facial nerve as a polyetiological and monopathogenetic disease $[2$, p. $842 ; 3$, p. 445; 4, p. 985; 5 , p. $353 ; 14$, p. 743]. The main etiological factors of the facial nerve neuropathy are the following: otogenic, traumatic, compression factors, vascular diseases, intoxication, anomalies of development of the inner ear and tumor processes in the cerebellopontine angle, viral lesions of the knee ganglion [5, p. 353; 8, p. 147; 15, p. 113; 16, p. 57]. Not so common reason, mainly in adults, there are other causes of facial nerve damage, such as diabetes mellitus, arterial hypertension, AIDS, Lyme disease, sarcoidosis, Sjogren's syndrome, amyloidosis, Ramsey-Hunt syndrome, iatrogenic factors $[7$, p. $888 ; 15$, p. 113; 17, p. 47; 22, p. 313].

In pediatric patients, the largest part consists of patients in whom the disease occurs due to hypothermia, general infection, or in the form of so-called idiopathic facial neuropathy.

Autonomic dysfunction, according to the literature and our research data is a required component of clinical characteristics neuropathy of the facial nerve $[19$, p. $87 ; 21$, p. 72]. A deeper study is interesting from the standpoint of the possibility of optimizing of treatment strategy for this disease by correcting autonomic disorders. "Gold standard" for studying the functional assessment of regulatory systems of an organism, the sympathetic and parasympathetic divisions of autonomic nervous system is assesment of heat rate variability [17, p. 47; 18, p. 163]. This method is widely used to establish the dynamics of cardiovascular autonomic dysfunction, depending on the nature and location of stroke, study of the effectiveness of mezodientcephalic modulation treatment for patients with acute poisoning by psychotropic drugs, evaluation of autonomic reactivity in children with spinal birth injuries as markers of physiological reserves in the remote period $[18$, p. $165 ; 27$, p. 35].

The problem of expansion of the effective treatment of facial nerve neuropathy in children remains valid, since this pathology is most common among acute lesions of cranial nerves and is the first among the diseases 
of the peripheral nervous system. Leading pathogenesis of the disease is primary ischemia - swelling - compression - secondary ischemia. The result of a long and severe nerve compression is demyelization and secondary degeneration of nerve fibers $[10$, p. $38 ; 23$, p. $57 ; 24$, p. 16]. The perspective in this direction is to study the markers of hypoxia, such as lactate and pyruvate in the blood, as they reflect changes in decrease of tissue oxygenation. The literature suggests that the content of lactate and pyruvate are key energy metabolites, considered as criteria for evaluating energy of homeostasis in many pathological conditions, including cystic fibrosis, chronic gastroduodenitis, acute bleeding and pancreatitis, intestinal obstruction, phlegmon of the maxillofacial area [20, p. 47].

Based on the mechanisms of pathogenesis, usage in treatment of Thiotriazoline is appropriate, because it has integrated anti-ischemic, antioxidant, immunomodulatory and anti-inflammatory actions, and it has expressed sanogenetic properties [20, p. 50;21, p. 72]. Its complex mechanism of action is due to the presence of tio-group in its structure, which ensures the recovery of active oxygen species, blockade of their formation, ways of intensifying glycolytic, ATP production, activates lactate-dehydrogenase reaction that results in lactate levels decreases. The drag is widely used in cardiology and ophthalmology $[19$, p. $89 ; 20$, p. 50; 21, p. 72]. In neurological practice, it has found application in traumatic brain injuries as a neuroprotective $[19$, p. $89 ; 20$, p. $50 ; 21$, p. 72$]$. Thus, the pharmacological properties of the medicine, including anti-ischemic, antioxidant and sanogenetic action, as well as its low toxicity, gives the opportunity to justify its use in the treatment of facial nerve neuropathy in children.

The aim of the study was to investigate markers of hypoxia - lactate and pyruvate - in children with facial nerve neuropathy in relation to the severity of the dysfunction of the "facial nerve - facial muscles" on a scale House-Brackmann and increase the effectiveness of treatment by correcting the redox imbalance.

\section{Materials and methods}

The study involved 122 children with acute facial nerve neuropathy, who had treatment in the department for children with organic lesions of the central nervous system and dysfunction of the musculoskeletal system at Ivano-Frankivsk Regional Children's Hospital. 
We performed clinical and neurological examination for all patients. Particularly we established the degree of dysfunction of the "facial nerve facial muscles" on a scale of House-Brackmann, determined the level of lactate and pyruvate in blood and also performed standard examination attached in the Annex to Order № 502 dated 28.12.2002 "Interim standards of medical care" in the direction of child neurology and Annex to Order № 226 dated 27.07.1998.

Many national and foreign scales have been proposed for clinical assessment of the degree of facial nerve damage and motor dysfunction of facial muscles [1, p. 160; 15, p. 116; 26, p. 1415].

The most commonly used scales are:

- Botman and Jongkees;

- May;

- Peitersen;

- K. Rosler grading Scale;

- House-Brackmann;

- Smith Scale;

- Yanagihara Scale;

- Janssen's Scale;

- Sunnybrook Scale.

Most of them, particularly Botman and Jongkees, Peitersen, K. Rosler, are 5-grades scales and includes:

0 grade - normal function of the mimic muscles;

I grade - slight paresis: there is no asymmetry at rest and during speaking, no lagophthalmus, slight asymmetry during smiling and whistling;

II grade-moderate paresis: there is no asymmetry at rest, lagophthalmus, asymmetry during smiling and speaking;

III grade - severe paresis: asymmetry at rest;

IV grade - plegia: atonia, complete loss of function.

The May scale consists of five grades severity of mimic muscles dysfunction and includes etiological factors and prognosis of recovering. For example, according to this scale, the II grade (slight paresis) represents non-full lesion of facial nerve, caused by herpes simplex virus, otitis, temporal bone injury or Bell's palsy and positive outcomes.

III-V grades (moderate and severe paresis) represent complete lesion of facial nerve, cause by injury or brain tumor. Prognosis is relatively favorable 
for grade III and unfavorable for grade IV (face is symmetric only at rest) and negative for grade $\mathrm{V}$.

Disadvantages of these scales are following: inability to grade the slight changes in mimic muscles function, especially during recovery; lack of reliability of assessment; probability of error of the researcher; secondary defects are not taken into account.

Among the national scales deserves attention the scale by Ya.S. Balaban. According to this scale, the available clinical manifestations are analyzed based on a 5-point score, the physiological norm receives the maximum number of points -5 points.

A score of 4 points receives a condition where the patient can close his eye, raise his eyebrows, wrinkle his forehead, but with less force than on the healthy side. 4-5 teeth are visible, the mouth is hardly noticeably dragged to the healthy side. A patient inflates the cheek, but with less force than on the opposite side. ENMG study detects the latency 4.5-5.0 ms.

Score 3 points - the patient is able to close his eye, but there is a positive symptom of "eyelashes"; he can inflate and raise eyebrows, wrinkle its forehead, but less than on the healthy side, he cannot overcome the researcher's resistance. 3-4 teeth are visible; the patient cannot whistling, can inflates the cheek but cannot overcome the researcher's resistance. In the ENMG study, the latency is 5.0-5.5 ms.

Score 2 points - the eye is not completely closed - lagoftalmus is 1-2 $\mathrm{mm}$; the patient's forehead wrinkles slightly, slight movements of the eyebrow are noted; 2-3 teeth are visible; whistling is impossible. In the ENMG study, the latency is 5.5-6.0 ms.

A score of 0 points characterizes complete paralysis of mimic muscles the patient does not close the eye (lagoophthalmus more than $5 \mathrm{~mm}$ ), cannot raise eyebrow, the angle of the mouth on the side of the lesion is stationary; whistling impossible, mouth sharply distorted in the healthy side. During ENMG stimulation, the M-response is not elicited.

3-4 points on the scale of Ya.S. Balaban characterizes the mild course, 2 points - moderate, 1-0 points indicate a severe course of the disease.

Validity and objectivity of the Ya.S. Balaban scale are significantly increased by definition and evaluation of stimulation ENMG. It should be noted that according to the literature and own studies, the ENMGnormalization is slower than clinical recovering of mimic muscle. That is 
why this scale is not quite good for evaluation of the recovering process of the system "facial nerve - mimic muscles".

There is also a group of so-called "regional scales", among which the most used scales are Smith, Yanagihara, Janssen's, Sunnybrook.

Thus, the Smith scale, evaluates the function of mimic muscles as a percentage for each part separately, at rest and during motor activity. The part for evaluating are the following: frontal abdomen of the frontoccipital muscle, the circular muscles of the eye and mouth. In particular, 0 grade corresponds to $0 \%$ of function, I grade $-0-25 \%$ of function, II grade $-25-50 \%$, III grade $-50-75 \%$, IV grade $-75-100 \%$. The next step is to transfer the percentage of muscle function from 0 (no function) to 4 (normal) and calculate the arithmetic mean.

Use of the Yanagihara scale evaluate the function of facial muscles by 10 parameters according to the following states: rest, wrinkles on the forehead, blinking, light eyelid closure, close eyelid closure, eye closure only on the affected side, wrinkles on the nose, whistling, smiling, weakness of lower lip. The score is in points in the following direction: 4 points normal, 3 - mild paresis, 2 - moderate paresis, 1 - severe paresis, 0 - plegia.

This scale is useful for comparing the function of mimic muscle in points during the treatment stages.

The Janssen's scale gives an opportunity to evaluate the function of mimic muscles separately in different areas, particularly, the condition at rest, during motor activity of the frontal abdomen of the front-occipital muscle, the circular muscles of the eye and mouth in percent. The next step is calculating of the result according to a weighting factor of each zone: 0.1 for the forehead, 0.3 eye and mouth and state at rest and calculating the arithmetic mean.

The disadvantages of these three scales are following: they do not take into account secondary defects in facial nerve neuropathy, a fairly high level of variability of results in different researchers, the complexity of evaluating of the facial muscles function in percents.

The evaluation of functioning of the system "facial nerve - mimic muscles" by Sunnybrook ccale is carried out in 4 stages:

- 1st stage - evaluation of facial muscles in points at rest for areas of the eye, cheeks, mouth (0-2). Points are summed up, the result is multiplied by 5 ; 
- 2nd stage - evaluation of mimic muscles in points (1-5) during voluntary movements, particularly, eyebrow movements, smiling, lip wrinkles. Points are summed up, the result is multiplied by 4;

- Stage 3 - evaluation of synkinesis in eyebrow movements, light eyelid closure, smiling, wrinkling of lips (0-3), points are summed;

- Stage 4 - from the score of voluntary movements the resting score and the syncinesis score are subtracted. However, this scale is time consuming and has a high degree of subjectivity in evaluations.

The most widely used in practice is the House-Brackmann scale, which includes five levels of mimic muscle dysfunction. Muscle weakness, symmetry, syncinesis, and mimic contractions correspond to each level:

I degree - normal function of all branches;

II degree - mild dysfunction:

a) slight weakness, slight synkinesis are possible;

b) the face at rest is symmetrical, facial expression like usually;

c) slight movements of the eyebrows, the eye is completely closed at effort;

d) slight asymmetry of the mouth;

Grade III - moderate dysfunction:

a) visible but not distorting asymmetry;

b) unexpressed synkinesia;

c) slight movements of the eyebrows, the eye is completely closed at effort, slight asymmetry of the mouth during maximum effort;

Grade IV - moderate dysfunction:

a) visible weakness or distorting asymmetry;

b) the eyebrow movements are absent the eye is closed incompletely;

c) asymmetry of the mouth during maximum effort;

V degree - severe dysfunction:

a) barely noticeable movements of facial muscles;

b) asymmetrical face at rest;

VI degree - total paralysis.

In a comparative aspect, the House-Brackmann scale is the most optimal in the complex assessment of the severity of prosoparesis in patients during acute period and with incomplete recovering of facial nerve function, when the development of pathological synkinesis and contractions of facial muscles often occurs in the clinical course. 
The severity of lesion of the "facial nerve - mimic muscles" was following. In $12(9.8 \%)$ children was moderate dysfunction - grade III by the House-Brackmann scale. 97 (79.5\%) children had moderate dysfunction grade IV by the House-Brackmann scale. 13 (10.7\%) children had severe dysfunction - grade V by the House-Brackmann scale.

In addition to facial asymmetry, 7 patients $(5.74 \%)$ complained of earache or parotid pain, $2(1.64 \%)$ - half-face swelling before asymmetry occurred, $13(10.7 \%)$ - taste disturbance, $1(0.82 \%)$ - for twitching of the eyelid on the affected side, as much for taste impairment combined with eyelid twitching, another $1(0.82 \%)$ for taste, hearing disturbances, and eyelid twitching.

The level of facial nerve damage was determined by additional symptoms: in $107(87.7 \%)$ patients, facial nerve lesions were reported at the exit of the canal. This corresponds to the literature data $[6$, p. 59; 11, p. 45; 15 , p. $116 ; 16$, p. $58 ; 24$, p. $7 ; 27$, p. 36$]$, as in the lower part of the canal is the most thickened and elastic epineurium and conditions for compression here are particularly favorable. In $15(12.3 \%)$ children there was an intracanal lesion, including $14(11.48 \%)$ of them above the corda tympani and in 1 case $(0.82 \%)$ above the n.stapidius.

54 children with facial nerve neuropathy and 12 healthy children aged $14,67 \pm 0,68$ years were examined by assessment of heart rate variability.

Assessment of heart rate variability was performed for the patients during 1-3 days and 8-11 days of treatment with the automatic processing of registered quantitative parameters of heart rate variability (HRV) using the system KARDYOLAB.

In order to determine vegetative background and autonomic reactivity at rest and while performing active orthostatic test, the following parameters were analyzed:

- Am0 - amplitude of moda - displays the status of the sympathetic nervous system;

- RMSSD - the same for parasympathetic nervous system;

- TI1 - tension index - indicates the voltage and centralization of regulatory mechanisms of the autonomic nervous system (ANS;

- Ratio TI2/TI1 - reflects reactivity of ANS;

Also spectrum analysis data:

- TP - total spectral power characterizes the overall regulatory mechanisms (activity of ANS); 
- VLF - very low frequency - associated with the influence of suprasegmental part of sympathetic ANS;

- LF - low frequency shows mainly on the activity of the sympathetic level ANS;

- HF - high-frequency oscillations reflecting parasympathetic activity;

- LF/HF - ratio of low-and high-frequency oscillations sympatho-vagal index.

We formed 4 groups of patient similar by age and clinical course and prescribed different scheme of treatment. 30 patients from the first group received standard treatment, which was carried out according to the Annex to Order № 502 dated 28.12.2002 "Interim standards of medical care" in the direction of child neurology, 31 patients from the second Group - standard therapy was combined with the use of drug thiotriasolin in the form of $2,5 \%$ solution intramuscularly during 10 days. Patients of the third group (31 patients) - the treatment scheme included nucleo CMP forte orally 1 capsule twice a day during 20 days. 30 patients from the fourth group treatment included thiotriasolin medicine and nucleo CMP forte.

\section{Heart rate variability in children with facial nerve neuropathy}

All patients at the beginning of disease compared with the control group demonstrated a significant increase of sympathetic nervous system in terms Am0, decreased tone of the parasympathetic nervous system in terms of RMSSD, growth rate tension index (TI) at 2,02 times, indicating the tension of regulatory mechanisms of autonomic nervous system. Also we detected increasing of the TI2/TI1 ratio in 1,57 times, which reflects the increased reactivity of ANS (table 1).

Table 1

\section{Setup time analysis of HRV in healthy children} and children with facial nerve neuropathy

\begin{tabular}{|l|c|c|c|c|c|}
\hline & Amo & RMSSD & TI1 & TI2 & TI2/TI1 \\
\hline $\begin{array}{l}\text { Healthy } \\
(\mathrm{n}=12)\end{array}$ & $37,67 \pm 1,88$ & $43,25 \pm 2,91$ & $103,00 \pm 8,74$ & $184,83 \pm 13,63$ & $1,89 \pm 0,15$ \\
\hline $\begin{array}{l}\text { Children with } \\
\text { FNN ( } \mathrm{n}=48)\end{array}$ & $49,07 \pm 2,36$ & $30,29 \pm 2,36$ & $207,74 \pm 17,86$ & $497,77 \pm 35,81$ & $2,96 \pm 0,20$ \\
\hline & $\mathrm{p}<0,05$ & $\mathrm{p}<0,05$ & $\mathrm{p}<0,05$ & $\mathrm{p}<0,05$ & $\mathrm{p}<0,05$ \\
\hline
\end{tabular}


The following levels of autonomic production and autonomic reactivity were established based on the level of TI1 and TI1/TI2 ratio among children with neuropathy of the facial nerve:

- Hypersympathytoniya; autonomic reactivity - hypersympathytonic $28,3 \%$;

- Eytoniya; autonomic reactivity - hypersympathytonic - 17,4\%;

- Sympathotonia; autonomic reactivity - hypersympathytonic - 26,1\%;

- Hypersympathytoniya; normal autonomic reactivity - 15,2\%;

- Eytoniya; normal autonomic reactivity - 4,3\%;

- Sympathotonia; normal autonomic reactivity - 4,3\%;

- Eytoniya; autonomic reactivity - asympathytonic - 2,2\%;

- Vagotonia; autonomic reactivity - hypersympathytonic - 2,2\% cases.

Among the children of the control group:

- Eytoniya; normal autonomic reactivity - 8,3\%;

- Eytoniya; hypersympathytonic - 33,3\%;

- Sympathotonia; normal autonomic reactivity - 33,3\%;

- Sympathotonia; autonomic reactivity hypersympathytonic $-25 \%$ cases.

According to spectral analysis data, comparing healthy children to those having neuropathy of the facial nerve, the total power of spectrum as well as very low frequency was practically unchanged. Reliably HF and LF part of the spectrum was increasing as well as sympatho-vagal index. The growth of the last one shows the increasing of sympathetic activity level of ANS (table 2).

Table 2

\section{Parameters of spectral analysis of HRV for healthy children and children with facial nerve neuropathy}

\begin{tabular}{|l|c|c|c|c|c|}
\hline & TP & VLF & LF & HF & LF/HF \\
\hline Healthy & $2963,83 \pm$ & $983,17 \pm$ & $267,33 \pm$ & $283,83 \pm$ & \multirow{2}{*}{$1,23 \pm 0,20$} \\
$(\mathrm{n}=12)$ & 347,09 & 112,96 & 138,87 & 152,44 & \\
\hline Children with & $2947,80 \pm$ & $931,24 \pm$ & $682,64 \pm$ & $973,69 \pm$ & \multirow{2}{*}{$1,58 \pm 0,17$} \\
FNN (n=48) & 270,79 & 103,75 & 82,62 & 137,14 & \\
\hline & & & $\mathrm{p}<0,05$ & $\mathrm{p}<0,05$ & \\
\hline
\end{tabular}

During active orthostatic test performance, indicators of temporal analysis varied similar to that obtained at rest, a significant increase in the ratio was only TI2/TI1 (see Table 3 ). 
Table 3

Setup time analysis of HRV in healthy children and children with facial nerve neuropathy during the orthostatic test

\begin{tabular}{|l|c|c|c|c|c|}
\hline & Amo & RMSSD & TI1 & TI2 & TI2/TI1 \\
\hline $\begin{array}{l}\text { Healthy } \\
(\mathrm{n}=12)\end{array}$ & $45,17 \pm 2,11$ & $21,00 \pm 1,94$ & $103,0 \pm 8,74$ & $184,83 \pm 13,63$ & $1,89 \pm 0,15$ \\
\hline $\begin{array}{l}\text { Children } \\
\text { with FNN } \\
(\mathrm{n}=48)\end{array}$ & $58,03 \pm 1,57$ & $10,68 \pm 0,48$ & $211,18 \pm 19,73$ & $375,02 \pm 18,61$ & $3,09 \pm 0,21$ \\
\hline & $\mathrm{p}<0,05$ & $\mathrm{p}<0,05$ & $\mathrm{p}<0,05$ & $\mathrm{p}<0,05$ & $\mathrm{p}<0,05$ \\
\hline
\end{tabular}

During active orthostatic test in the control group a significant drop in overall power spectrum occurred, reduction of its HF level was just noticeable, thus ultra-low-, low-frequency part and sympatho-vagal index grew significantly and reliably (tabl.4).

It's worth to note that normal reaction on orthostatic probe is a decline of total power spectrum, its high-frequency part and growth of ultralow- and low-frequency units, as well as the rate of sympathovagal balance.

Table 4

Parameters of spectral analysis of HRV in healthy children during the orthostatic test

\begin{tabular}{|l|c|c|c|c|c|}
\hline & TP & VLF & LF & HF & LF/HF \\
\hline $\begin{array}{l}\text { Healthy } \\
(\mathrm{n}=12)\end{array}$ & $\begin{array}{c}2963,83 \pm \\
347,09\end{array}$ & $\begin{array}{c}983,17 \pm \\
112,96\end{array}$ & $\begin{array}{c}267,33 \pm \\
138,87\end{array}$ & $\begin{array}{c}283,83 \pm \\
152,44\end{array}$ & $1,23 \pm 0,20$ \\
\hline $\begin{array}{l}\text { Healthy } \\
(\mathrm{n}=12),\end{array}$ & $2501,83 \pm$ & $761,42 \pm$ & $934,0 \pm$ & $227,75 \pm$ & $5,51 \pm 1,30$ \\
$\begin{array}{l}\text { orthostatic } \\
\text { test }\end{array}$ & 293,53 & 81,87 & 150,86 & 42,89 & \\
\hline & & & & & $\mathrm{p}<0,05$ \\
\hline
\end{tabular}

Indicators of spectral analysis during orthostatic test in children with facial nerve neuropathy showed more significant, compared to control group, reduction of the overall power spectrum and all its parts, increasing of sympatho-vagal index, herewith indicating the overreaction HRV and lack of activity of slow and middle regulation. 
Table 5

\section{Parameters of spectral analysis of HRV in children}

with neuropathy of the facial nerve during the orthostatic test

\begin{tabular}{|l|c|c|c|c|c|}
\hline & TP & VLF & LF & HF & LF/HF \\
\hline Children & $2947,80 \pm$ & $931,24 \pm$ & $682,64 \pm$ & $973,69 \pm$ & $1,58 \pm 0,17$ \\
with FNN & 270,79 & 103,75 & 82,62 & 137,14 & \\
$(\mathrm{n}=48)$ & & & & & \\
\hline $\begin{array}{l}\text { Children } \\
\text { with FNN }\end{array}$ & $1158,30 \pm$ & $424,02 \pm$ & $413,55 \pm$ & $158,81 \pm$ & $6,06 \pm 0,33$ \\
$(\mathrm{n}=48)$, & 99,84 & 35,72 & 28,75 & 8,59 & \\
$\begin{array}{l}\text { orthostatic } \\
\text { test }\end{array}$ & & & & & \\
\hline & $\mathrm{p}<0,05$ & $\mathrm{p}<0,05$ & $\mathrm{p}<0,05$ & $\mathrm{p}<0,05$ & $\mathrm{p}<0,05$ \\
\hline
\end{tabular}

Comparative characteristics of HRV during orthostatic test for healthy children and children with facial nerve neuropathy are represented in Table 6.

Table 6

Parameters of spectral analysis of HRV in healthy children and children with neuropathy of the facial nerve during the orthostatic test

\begin{tabular}{|l|c|c|c|c|c|}
\hline & TP & VLF & LF & HF & LF/HF \\
\hline $\begin{array}{l}\text { Healthy } \\
(\mathrm{n}=12),\end{array}$ & $2501,83 \pm$ & $761,42 \pm$ & $934,0 \pm$ & $227,75 \pm$ & \\
orthostatic & 293,53 & 81,87 & 150,86 & 42,89 & $5,51 \pm 1,30$ \\
test & & & & & \\
\hline $\begin{array}{l}\text { Children } \\
\text { with FNN } \\
\text { (n=48), } \\
\text { orthostatic } \\
\text { test }\end{array}$ & $\begin{array}{c}1158,30 \pm \\
99,84\end{array}$ & $\begin{array}{c}424,02 \pm \\
35,72\end{array}$ & $\begin{array}{c}413,55 \pm \\
28,75\end{array}$ & $\begin{array}{c}158,81 \pm \\
8,59\end{array}$ & \multirow{2}{*}{$6,06 \pm 0,33$} \\
\hline & $\mathrm{p}<0,05$ & $\mathrm{p}<0,05$ & $\mathrm{p}<0,05$ & & \\
\hline
\end{tabular}

\section{The role of the redox processes in clinical course of facial nerve neuropathy}

The level of lactate in the blood of patients with facial nerve neuropathy at baseline was increased and most pronounced in severe dysfunction of the "facial nerve - facial muscles» (Vth degree by House-Brackmann scale). In the third and fourth degrees of dysfunction increase in lactate did not reach statistically significant levels (Table 7). 
Table 7

The level of lactate $(\mathrm{mmol} / \mathrm{l})$ in patients with facial nerve neuropathy compared with control $(\mathbf{M} \pm \mathbf{m})$

\begin{tabular}{|c|c|c|c|c|}
\hline \multirow{2}{*}{$\begin{array}{c}\text { The control } \\
\text { group }(\mathbf{n}=\mathbf{9})\end{array}$} & \multicolumn{4}{|c|}{ Patients with facial nerve neuropathy $(\mathbf{n}=\mathbf{4 0})$} \\
\cline { 2 - 5 } & Mean & The level at various stages of dysfunction \\
\cline { 2 - 5 } & & III & IV & V \\
\hline $0,15 \pm 0,02$ & $0,23 \pm 0,04 *$ & $0,09 \pm 0,01$ & $0,21 \pm 0,04$ & $0,38 \pm 0,11$ \\
\hline
\end{tabular}

Note: * significantly compared with the control group, $\mathrm{p}<0.05$

We found a direct correlation between the severity of facial palsy and lactate levels, as indicated by the value of Pearson's coefficient of +0.35 .

In all the patients there was a significant reduction of pyruvate in early disease course with severe facial palsy (Table 8), which is also confirmed by strong direct correlation (Pearson coefficient +0.82 ).

Table 8

The level of pyruvate $(\mathrm{mcmol} / \mathrm{l})$ in patients with facial nerve neuropathy compared with control $(\mathbf{M} \pm \mathbf{m})$

\begin{tabular}{|c|c|c|c|c|}
\hline \multirow{2}{*}{$\begin{array}{c}\text { The control } \\
\text { group }(\mathbf{n}=\mathbf{1 0})\end{array}$} & \multicolumn{4}{|c|}{ Patients with facial nerve neuropathy $(\mathbf{n}=\mathbf{4 2})$} \\
\cline { 3 - 5 } & \multirow{2}{*}{ Mean } & \multicolumn{3}{|c|}{ The level at various stages of dysfunction } \\
\cline { 3 - 5 } & & III & IV & V \\
\hline $41,8 \pm 0,76$ & $30,38 \pm 0,42 *$ & $36,25 \pm 1,06$ & $33,0 \pm 0,3 *$ & $27,13 \pm 0,51 *$ \\
\hline
\end{tabular}

Note: * significantly compared with the control group, $\mathrm{p}<0.05$

The increase in lactate and a low level of pyruvate in patients with facial nerve neuropathy can be explained by the fact that, when there is oxygen deficiency, more glucose is converted to lactate to form 2 molecules of ATP instead of 34 in the metabolism of the Krebs cycle. In the long-term retention anaerobic conditions lactate is not oxidized to pyruvate through the lack of NAD. These biochemical changes, especially in relation with the degree of dysfunction of the facial nerve on a House-Brackmann scale, indicate a significant role of violation of redox processes in determining the characteristics of the dynamics of the disease and the degree of dysfunction of the facial nerve.

After 14 days of treatment, the decrease of lactate in all groups was observed: in the first group to $60.9 \%$ in the second $-84 \%$, in the third - 
$61.9 \%$ in fourth - by $87.5 \%$, but in groups I and III level of reliability has been achieved. The level of pyruvate increased in the first group to $8.7 \%$ in the second $-22.6 \%$, in the third - by $9.6 \%$ in the IV - $18.1 \%$, these changes were statistically significant in the second and fourth groups (Table 9 and Table 10).

Table 9

Comparative evaluation of changes of lactate $(\mathrm{mmol} / \mathrm{l})$ in patients with facial nerve neuropathy during treatment, $(\mathrm{M} \pm \mathbf{m})$

\begin{tabular}{|c|c|c|c|c|c|c|c|c|}
\hline \multirow{3}{*}{$\begin{array}{c}\text { Control } \\
(\mathrm{N}=9)\end{array}$} & \multicolumn{4}{|c|}{ Before treatment } & \multicolumn{4}{|c|}{ After treatment } \\
\hline & \multicolumn{4}{|c|}{ Groups of patients } & \multicolumn{4}{|c|}{ Groups of patients } \\
\hline & $\begin{array}{c}I \\
(N=10)\end{array}$ & $\begin{array}{c}\text { II } \\
(\mathbf{N}=\mathbf{1 0})\end{array}$ & $\begin{array}{c}\text { III } \\
(\mathbf{N}=\mathbf{1 0})\end{array}$ & $\begin{array}{c}\text { IV } \\
(\mathbf{N}=\mathbf{1 0})\end{array}$ & $\begin{array}{c}I \\
(N=10)\end{array}$ & $\begin{array}{c}\text { II } \\
(\mathrm{N}=\mathbf{1 0})\end{array}$ & $\begin{array}{c}\text { III } \\
(\mathbf{N}=10)\end{array}$ & $\begin{array}{c}\text { IV } \\
(\mathrm{N}=\mathbf{1 0})\end{array}$ \\
\hline $\begin{array}{c}0,15 \pm \\
0,02\end{array}$ & $\begin{array}{c}0,23 \\
\pm 0.07\end{array}$ & $\begin{array}{c}0,25 \\
\pm 0.07\end{array}$ & $\begin{array}{c}0,21 \\
\pm 0.07\end{array}$ & $\begin{array}{c}0,24 \\
\pm 0.07\end{array}$ & $\begin{array}{c}0,09 \\
\pm 0.01\end{array}$ & $\begin{array}{l}0,04 \pm \\
0.01 *\end{array}$ & $\begin{array}{c}0,08 \pm \\
0.01\end{array}$ & $\begin{array}{l}0,03 \pm \\
0,01 *\end{array}$ \\
\hline
\end{tabular}

Note: * significantly compared with control, $\mathrm{p}<0.05$

$* *$ Significantly when comparing before and after treatment, $\mathrm{p}<0.05$.

Table 10

Comparative evaluation of changes in pyruvate content ( $\mathrm{mcmol} / \mathrm{l})$ in patients with facial nerve neuropathy during treatment, $(\mathbf{M} \pm \mathbf{m})$

\begin{tabular}{|c|c|c|c|c|c|c|c|c|}
\hline \multirow{3}{*}{$\begin{array}{l}\text { Control } \\
(\mathrm{N}=\mathbf{1 0})\end{array}$} & \multirow{2}{*}{\multicolumn{4}{|c|}{$\begin{array}{l}\text { Before treatment } \\
\text { Groups of patients }\end{array}$}} & \multirow{2}{*}{\multicolumn{4}{|c|}{$\begin{array}{c}\text { After treatment } \\
\text { Groups of patients }\end{array}$}} \\
\hline & & & & & & & & \\
\hline & $\begin{array}{c}I \\
(N=11)\end{array}$ & $\begin{array}{c}\text { II } \\
(\mathbf{N}=\mathbf{1 0})\end{array}$ & $\begin{array}{c}\text { III } \\
(\mathbf{N}=\mathbf{1 0})\end{array}$ & $\begin{array}{c}\text { IV } \\
(N=11)\end{array}$ & $\begin{array}{c}I \\
(N=10)\end{array}$ & $\begin{array}{c}\text { II } \\
(\mathbf{N}=\mathbf{1 0})\end{array}$ & $\begin{array}{c}\text { III } \\
(\mathbf{N}=\mathbf{1 0})\end{array}$ & $\begin{array}{c}\text { IV } \\
(N=11)\end{array}$ \\
\hline $\begin{array}{c}41,8 \\
\pm 0.76\end{array}$ & $\begin{array}{l}30,55 \\
\pm 0.96 *\end{array}$ & $\begin{array}{c}30,10 \pm \\
0.46 *\end{array}$ & $\begin{array}{c}30,20 \\
\pm 0.82 *\end{array}$ & $\begin{array}{l}30,64 \\
\pm 0.97 *\end{array}$ & $\begin{array}{l}33,20 \\
\pm 0.83\end{array}$ & $\begin{array}{l}36,90 \\
\pm 0.26 \\
* *\end{array}$ & $\begin{array}{l}33,10 \\
\pm 0.88 \\
* *\end{array}$ & $\begin{array}{l}36,18 \\
\pm 0.70 \\
* *\end{array}$ \\
\hline
\end{tabular}

Note: * significantly compared with control, $\mathrm{p}<0.05$

** Significantly when comparing before and after treatment, $\mathrm{p}<0.05$.

The results are the can be evidence of use of Thiotriazoline in the complex therapy of facial nerve neuropathy. In case of ischemic damage of tissue, Thiotriazoline regulates the disposal of glucose and glycogen in the cell, the activity of glucose-6-phosphate dehydrogenase, increases the ratio of NAD/NADH and activity of cytochrome-C-oxidase, increases the level of pyruvate, while reducing lactate hyperproduction. Positively affecting to the utilization of reduced forms of pyridine nucleotide, 
thiotriasolin significantly inhibits formation of reactive oxygen species and oxidative phosphorylation, activated formation of ATP. The protective effect of Thiotriazoline during ischemia realized by activating malateaspartate "lock" mechanism, which provides by protons electron-transport chain. In ischemic cells and tissues Thiotriasolin significantly inhibits the accumulation of free amino acids, activates the process of protein synthesis, indicating the initiation of adaptation, that provides rebuilding tissue metabolism in hypoxic conditions without increasing oxygen demand and the formation of free radicals [20, p. 51].

\section{Clinical course and the outcomes of the pediatric facial nerve neuropathy}

Positive clinical dynamics in all examined patients were recorded: severity of facial palsy was decreased, but its extent and rate of recovery of facial muscles function varied in different groups of treatment. In the first group of treatment, $40.00 \%$ of patients were discharged with the full recovery. In $60,00 \%$ cases in-patient treatment was postponed, the degree of facial muscles dysfunction among those discharged was the second degree by House-Brackmann scale at $72,20 \%$, third degree - in $16,70 \%$, IV degree - at $11.10 \%$. The average term of hospitalization in this group was $19,70 \pm 1,18$ days. Full recovering of function of facial muscles was observed at the control examination after 2 weeks in $43.30 \%$ of patients. In $16.70 \%$ of patients in this group the disease became protracted, there have been repeated courses of treatment. In long-term outcome in $6.7 \%$ of patients contracture of facial muscles was formed.

In the second group, $61.30 \%$ of patients were discharged with the full recovery, in $38.70 \%$ of cases in-patient treatment was postponed, the degree of dysfunction of the facial muscles among those discharged was consistent with the second degree by House-Brackmann scale. The average term of hospitalization in this group was $13,45 \pm 0,69$ days. At the control examination after 2 weeks, the complete recovery of facial muscles function took place.

In the third group, $48.40 \%$ of patients were discharged from the recovery, in $51.60 \%$ of cases in-patient treatment was postponed. Among those discharged patients with dysfunction of facial muscles, the second degree by House-Brackmann scale was in $56.30 \%$ of patients, third degree - 
in $31,30 \%$, IV degree - at $12.50 \%$. The average term of hospitalization in this group was $20,77 \pm 1,15$ days. Among those discharged with improvement in $19.35 \%$ of cases patients recovered completely within 2 weeks after discharge, at $12.90 \%$ - after a month. In $19.35 \%$ of patients in this group the disease became protracted, there have been repeated courses of treatment; later in $6.45 \%$ of patients was formed contractures of facial muscles.

In the IVth group, complete recovery occurred in $63.30 \%$ of patients. In $36.70 \%$ of cases of hospital treatment it was postponed, the dysfunction of the facial muscles among those discharged was consistent with the second degree by House-Brackmann scale. The average term of hospitalization in this group was $14,40 \pm 1,03$ days. About $20 \%$ of children with facial muscles function recovered completely within 2 weeks after discharge, at $13.37 \%$ - after a month. In 1 patient in this group $(3.33 \%)$ the disease

Table 11

\section{Clinical indicators of catamnesis in patients with facial nerve neuropathy}

\begin{tabular}{|l|c|c|c|c|}
\hline \multirow{2}{*}{} & \multicolumn{4}{|c|}{ Treatment groups } \\
\cline { 2 - 5 } & I & II & III & IV \\
\hline $\begin{array}{l}\text { Discharged with improvement } \\
\text { during inpatient treatment }\end{array}$ & $60.00 \%$ & $38.70 \%$ & $51.60 \%$ & $36.70 \%$ \\
\hline $\begin{array}{l}\text { Complete clinical recovery within } 2 \\
\text { weeks after discharge from hospital }\end{array}$ & $40.00 \%$ & $38.70 \%$ & $19.35 \%$ & $20.00 \%$ \\
\hline $\begin{array}{l}\text { Complete clinical recovery 1 month } \\
\text { after discharge from hospital }\end{array}$ & $3.30 \%$ & $-12.90 \%$ & $13.37 \%$ & \\
\hline Protracted course of the disease & $16.70 \%$ & $-19.35 \%$ & $3.33 \%$ & \\
\hline Contracture of facial muscles & $6.70 \%$ & $-6.45 \%$ & - & \\
\hline
\end{tabular}

Table 12

Clinical effectiveness of in-patient treatment in children with facial nerve neuropathy in the study groups

\begin{tabular}{|l|c|c|c|c|}
\hline \multirow{2}{*}{} & \multicolumn{4}{|c|}{ Treatment groups } \\
\cline { 2 - 5 } & I & II & III & IV \\
\hline $\begin{array}{l}\text { Duration of } \\
\text { hospitalization }\end{array}$ & $19,70 \pm 1,18$ & $13,45 \pm 0,69$ & $20,77 \pm 1,15$ & $14,40 \pm 1,03$ \\
\hline $\begin{array}{l}\text { Full recovery during } \\
\text { inpatient treatment }\end{array}$ & $40.00 \%$ & $61.30 \%$ & $48.40 \%$ & $63.30 \%$ \\
\hline
\end{tabular}


became protracted, there have been repeated courses of treatment, after which the function of facial muscles recovered completely.

Overall clinical effectiveness of the inpatient treatment and case history data reflected in the table 11 and 12 .

\section{Conclusions}

1. Facial nerve neuropathy is the most common disease of the cranial nerve in children and mainly caused by local or general hypothermia, general infection, or is the form of so-called idiopathic facial neuropathy. The level of facial nerve damage in $87.7 \%$ patients were reported at the exit of the canal, as in the lower part of the canal is the most thickened and elastic epineurium and conditions for compression here are particularly favorable. In $15(12.3 \%)$ children there was an intra-canal lesion, including $14(11.48 \%)$ of them above the corda tympani and in 1 case $(0.82 \%)$ above the n.stapidius.

2. House-Brackmann scale is the most optimal in the complex assessment of the severity of prosoparesis in patients during acute period and with incomplete recovering of facial nerve function, when the development of pathological synkinesis and contractions of facial muscles often occurs in the clinical course

3. Imbalance of sympathetic and parasympathetic parts, excessive response of heart rate variability to orthostatic probe and to the lack of activity of slow and middle regulation are accompanying clinical course of neuropathy of the facial nerve. These changes from the first days of the disease indicate the dysadaptation of the organism, and may be not only indicators of neuropathy of the facial nerve, but also the background for its appearance.

4. There was direct correlation between the severity of facial palsy and lactate level (Pearson's coefficient +0.35 ): the level of lactate in the blood of patients with facial nerve neuropathy at baseline was increased and most pronounced in case of 5 th degree by House-Brackmann scale. In all patients with severe facial palsy was observed a significant reduction of pyruvate (Pearson's coefficient +0.82 ). Correlations between biochemical changes and clinical severity rate indicate a significant role of violation of redox processes in the dynamics of the disease and provide a suggestion that correction of redox processes can improve the outcomes of treatment. 
5. Significant decreasing in lactate and pyruvate expanse, especially in patients who received thiotriazolin, could be an evidence of its role and effectiveness on the redox processes, one of the mechanisms for the implementation of which is to activate lactate-dehydrogenase reaction. It results in transformation lactate into pyruvate, leading to a decrease in edema and acidosis, which are important links in the pathogenesis of facial nerve neuropathy.

6. Generally pediatric facial nerve neuropathy most often has positive prognosis with complete recovering, thought complications occurred in $3,3 \%$ of cases. The proposed scheme of treatment provides improvement of outcomes, particularly reduce the duration of treatment and incidence of complications such as contracture of mimic muscles.

\section{References:}

1. Alakram P., Puckree T. (2010). Effects of electrical stimulation on HouseBrackmann scores in early Bell's palsy. Physiotherapy Theory and Practice, vol. 26(3), pp. 160-166. DOI: 10.3109/09593980902886339

2. Berg T., Axelsson S., Engström M. (2009). The course of pain in Bell's palsy: treatment with prednisolone and valacyclovir. Otology Neurotology, vol. 30(6), pp. 842-846. DOI: 10.1097/MAO.0b013e3181ab31c8

3. Berg T., Bylund N., Marsk E. (2012). The effect of prednisolone on sequelae in Bell's palsy. Archives of Otolaryngology - Head and Neck Surgery (electronic journal), vol. 138, no 5, pp. 445-449. Available at: http://archderm.jamanetwork.com/ (accessed May 2012).

4. de Almeida J., Khabori M., Guyatt G. (2009). Combined corticosteroid and antiviral treatment for Bell palsy: a systematic review and meta-analysis. Journal of the American Medical Association, vol. 302, no 9, pp. 985-993. DOI: 10.1001/ jama.2009.1243

5. E. van der Veen, M. Rovers, J. de Ru (2012). A small effect of adding antiviral agents in treating patients with severe Bell palsy. Otolaryngology - Head and Neck Surgery, vol. 146(3), pp. 353-357. DOI: 10.1136/emermed-2013-20238

6. Grusha O., Ivanchenko Yu. (2011). Paralich licevogo nerva: topografichesie i patogeneticheskie osobennosti porazheniya [The paralysis of the facial nerve: topographical and pathogenetic features of defeat]. Vestnik oftal'mologii, no 3, pp. 59-61.

7. Kanazawa A., Haginomori S., Takamaki A. (2007). Prognosis for Bell's palsy: a comparison of diabetic and nondiabetic patients. Acta Oto-laryngologica, vol. 127(8), pp. 888-891. DOI: 10.1080/00016480601075399

8. Kawaguchi K., Inamura H., Abe Y. (2007). Reactivation of herpes simplex virus type 1 and varicella-zoster virus and therapeutic effects of combination therapy with prednisolone and valacyclovir in patients with Bell's palsy. Laryngoscope, vol. 117(1), pp. 147-156. DOI: 10.1097/01.mlg.0000248737.65607.9e 
9. Lee H., Byun J., Park M. (2013). Steroid-antiviral treatment improves the recovery rate in patients with severe Bell's palsy. The American Journal of Medicine, vol. 126(4), pp. 336-341. DOI: 10.1016/j.amjmed.2012.08.020

10. Levic'kij V., Shovkova N. (2009). Gisto-ul'trastruktura licevogo nerva v normi i v umovah eksperimental'noi nejropatii [Histological ultrastructure of facial nerve in normal and under experimental neuropathy]. Reports of morphology, vol. 15(1), pp. 38-43.

11. Lezhenko H., Pashkova O., Bilash V. (2011). Dosvid zastosuvannya nejrovitanu $\mathrm{v}$ terapii nevropatii lic'ovogo nerva [Experience of using of Neurovitan in treatment of facial nerve neuropathy]. International neurological journal, no 1(39), pp. 45-47.

12. Liu J., Li Y., Yuan X. (2009). Bell's palsy may have relations to bacterial infection. Medical Hypotheses, vol. 72(2), pp. 169-170. DOI: 10.1016/j.mehy. 2008.09.023

13. Lockhart P., Daly F., Pitkethly M., Comerford N., Sullivan F. (2009). Antiviral treatment for Bell's palsy (idiopathic facial paralysis). Cochrane Database of Systematic Reviews, Issue 4, Art. CD001869. DOI: 10.1002/14651858. CD001869.pub4

14. Lorch M., Teach S. (2010). Facial nerve palsy: etiology and approach to diagnosis and treatment. Pediatric Emergency Care, vol. 26(10), pp. 763-769. DOI: 10.1097/PEC.0b013e3181f3bd4a

15. Lyn'kov V., Poshyvalov Y. (2009). Travmaticheskie i netravmaticheskie zabolevaniya licevogo nerva - sovremennoe sostoyanie problemy [Traumatic and nontraumatic diseases of facial nerve - current state of problem]. Rossijskaya otorinolaringologiya, no 3(40), pp. 113-139.

16. Matvienko Yu., Bozhenko N. (2008). Neropatiya licevogo nerva [Facial nerve neuropathy]. Medytsyna svitu, no. XXV, pp. 57-65.

17. Mironenko T. (2010). Nejropatiya licevogo nerva u lic pozhilogo vozrasta: lechenie i profilaktika oslozhnenij [Neuropathy of the facial nerve in the elderly: treatment and prevention of complications]. Zdorov'ya Ukraini, no 1, p. 47.

18. Morozova T., Evtushenko S. (2011). Nevropatiya licevogo nerva i prozoparezy u detej [Neuropathy of the facial nerve and paresis of facial muscles in children]. International neurological journal, no 7(45), pp. 161-123.

19. Pityk M., Liskevych I. (2009). Nevropatiya licevogo nerva: osoblivosti patogenezu, diagnostiki i likuvannya u ditej ta pidlitkiv [Facial nerve neuropathy: especialities of pathogenesis, diagnostic and treatment in children and teenagers]. International neurological journal, no 1(23), pp. 85-90.

20. Pityk M., Liskevych I. (2013). Dinamika pokaznikiv endotelial'noi funkcii ta markeri gipoksii pri nevropatii licevogo nerva u ditej $\mathrm{v}$ procesi likuvannya [Dynamics of endothelial function and markers of hypoxia in children with facial nerve palsy during treatment]. Likars'ka sprava, no 7, pp. 47-51.

21. Pityk M., Liskevych I., Krishtafovich Ya., Kogut U., Dubovs'ka N. (2013). Dinamika variabel'nosti sercevogo ritmu u ditej z nevropatieyu licevogo nerva $\mathrm{v}$ procesi likuvannya [Dynamics of heart rate variability in children with facial nerve neuropathy during treatment]. Galic'kij likars'kij visnik, vol. 20, no 1, pp. 70-72. 
22. Ryu E., Lee H., Lee S. (2012). Clinical manifestations and prognosis of patients with Ramsay Hunt syndrome. Americal Journal of Otolaryngology, vol. 33(3), pp. 313-318. DOI: http://dx.doi.org/10/1016/j.amjoto.2011.10.001

23. Shovkova N., Levic'kij V. (2009). Dinamika elektronejromiografichnih rezul'tativ pri eksperimental'nij nejropatii licevogo nerva ta ii magnito-lazernij terapii [Dynamics of results of electroneuromyography in experimental facial nerve neuropathy and its magnetic-laser therapy]. Arhiv klinichnoi medicini, vol. 2(15), pp. 57-59.

24. Skripchenko N., Golyakov D., Pul'man N. (2008). Nevropatii licevogo nerva: klinicheskie osobennosti i vozhmozhnosti uluchsheniya ishodov [Neuropathy of the facial nerve: clinical features and the possibility to improve outcomes]. Detskie infekcii, vol. 7, no 3, pp. 16-24.

25. Suzuki T., Suzuki K., Oohata M. (2012). An investigation on prognostic diagnosis and therapeutic effects for peripheral facial nerve palsy. Masui, vol. 61(3), pp. 299-306. Available at: http://europepmc.org/abstract/med/22571125

26. Toffola E., Furini F., Redaelli C. (2010). Evaluation and treatment of synkinesis with botulinum toxin following facial nerve palsy. Disability and Rehabilitation, vol. 32(17), pp. 1414-1418. DOI: 10.3109/09638280903514697

27. Yavorskaya V., Pelehova O., Grebenyuk A. (2007). Neyropatyya lytsevoho nerva [Facial nerve neuropathy]. International medical journal, vol. 13, no 3, pp. 35-37. 